\title{
SELF-EXPERIMENTATION IN NUTRITION RESEARCH
}

\author{
ELSIE M. WIDDOWSON
}

Orchard House, Barrington, Cambridge CB2 5RA

\author{
CONTENTS
}

INTRODUCTION

SELF-OBSERVATION AND SELF-EXPERIMENTATION . . . . . 2

SANCTORIUS. A 17 TH-CENTURY SELF-OBSERVER . . . . . . . 2

WILLIAM STARK. AN 18 TH-CENTURY SELF-EXPERIMENTER . . . . . 3

THE PROTEIN REQUIREMENT OF MAN . . . . . . . . . . . . . . 4

SIVÉN AND CHITTENDEN. REQUIREMENT FOR PROTEIN ON A MIXED DIET . 4

MARTIN AND ROBISON. THE BIOLOGICAL VALUE OF PROTEINS . . . 5

THE UNRAVELLING OF THE FUNCTION OF THE VITAMINS . . . $\quad 6$

JOSEPH AND MARY GOLDBERGER. SELFEXPERIMENTATION AND THE

CAUSE OF PELLAGRA. . . . . . . . . . . . . . . . . . . . . . 6

JOHN CRANDON. SCURVY AND VITAMIN C . . . . . . . . . . . 7

VICTOR HERBERT. FOLIC ACID DEFICIENCY . . . . . . . . . . 7

DEFICIENCIES OF ELECTROLYTES AND WATER . . . . . . . 9

R. A. MCCANCE. EXPERIMENTAL SODIUM CHLORIDE DEFICIENCY . . . . 9

D. A. K. BLACK AND M. D. MILNE; PAUL FOURMAN. EXPERIMENTAL

POTASSIUM DEPLETION . . . . . . . . . . . . . . . . . 10

D. A. K. BLACK AND R. A. MCCANCE. WATER DEPLETION . . . . . 11

THE EXCRETION OF IRON, CALCIUM, MAGNESIUM AND

STRONTIUM.

MCCANCE AND WIDDOWSON. THE EXCRETION OF IRON AFTER

INTRAVENOUS ADMINISTRATION

MCCANCE AND WIDDOWSON. THE FATE OF CALCIUM AND MAGNESIUM

AFTER INTRAVENOUS ADMINISTRATION . . . . . . . . . . . $\quad . \quad 12$

MCCANCE AND WIDDOWSON. THE FATE OF STRONTIUM AFTER

INTRAVENOUS ADMINISTRATION . . . . . . . . . . . . . . . 13

THE DIET OF THE ESKIMO AND THE IMPORTANCE OF

POLYUNSATURATED FATTY ACIDS . . . . . . . . . . . . 13

HUGH SINCLAIR. A LONE SELF-EXPERIMENTER OF THE 1970S. . . . 13

CONCLUSIONS . . . . . . . . . . . . . . . . . . . . . . . 15

REFERENCES . . . . . . . . . . . . . . . . . . . . 16

\section{INTRODUCTION}

In 1987 a book was published in the USA entitled Who Goes First? The Story of Selfexperimentation in Medicine. The author, Lawrence K. Altman, devotes much of the book to the conquest of disease, such as the heroic efforts to test vaccines against infections and 
infestations. Examples are Pasteur's vaccine against rabies, Haffkine's against cholera, Wright's against yellow fever, Fforth's against malaria and Clyde's against hookworm. All these investigators deliberately acquired the disease in order to test the vaccine, often against great opposition from their colleagues. A different type of self-experimentation which is described in detail is Fossman's first catheterization of a human heart, his own, for which he won a Nobel prize. One chapter is devoted to self-experimentation in physiology, particularly the work of J. S. and J. B. S. Haldane, father and son. J. S. Haldane's studies on himself on respiration, the function of the lungs and the effects of poisonous gases are described; J. B. S. Haldane was clearly influenced by his father, and even as a boy participated in the experiments, descending into mines, climbing high mountains and making deep sea dives, and he accepted the risks associated with breathing methane and anaesthetics, and suffering lack of oxygen. Later he made his own experiments on himself, and he describes one of them in his essay 'On being one's own rabbit' (Haldane, 1940). He was investigating the effects of making the body more acid or more alkaline than normal. These were unpleasant but not dangerous for, as he says, 'they were done with intelligence'. Another chapter in Altman's book, entitled 'Dietary deprivation', is the only one primarily concerned with nutrition, and it deals almost entirely with self-experiments carried out in the 1920s and 1930s on deficiency of vitamins.

Nutrition seems to be a subject that would lend itself to self-experimentation, and in this paper I have attempted to explore this in more detail than Altman was able to do. The exploration is by no means exhaustive, but it serves to illustrate the variety of investigations that have been undertaken in which the investigator has used his own body to solve a problem.

\section{SELF-OBSERVATION AND SELF-EXPERIMENTATION}

There have been many definitions of 'research by observation' and 'research by experiment'. Claude Bernard (1865), in his Introduction to the Study of Experimental Medicine, entitles his first chapter 'Observation and experiment'. In it he describes how difficult it sometimes is to differentiate between the two. He quotes Zimmerman who stated that 'Knowledge gained through observation seems to appear of itself, while that which an experiment brings us is the fruit of an effort that we make with the object of knowing whether something exists or does not exist'. The distinction I have always accepted is that research by observation is observing and recording the course of events with as little interference as possible, for example measuring food intake, metabolic rate, urinary excretion of various substances, composition of blood and serum, or following body weight over a period of time. Research by experiment involves changing the conditions, for example taking what is regarded as too little or too much of a nutrient and studying the consequences, administering some substance by vein and studying its metabolism or excretion, or examining the effects of altering the environment in some way. In both types of study the investigator may use himself or herself as the subject of the investigation and he/she may work alone, or take part as the leader of a group. Self-observation is on the whole easier than self-experimentation, and it involves no risk, but it is often tedious and unexciting. Most of this paper will be devoted to self-experimentation.

\section{SANCTORIUS. A 17TH-CENTURY SELF-OBSERVER}

As the science of physiology began to develop in the 17th century, there were many aspects of the workings of the human body that were puzzling, for example the well known fact that, although a person consumes large quantities of food and drink, his weight does not 
change much throughout his adult life. Some of the ingested water and solids is clearly lost in urine and faeces, but this by no means accounts for it all. In 1614 Sanctorius made measurements on himself, and there is a well known woodcut, reproduced by Drummond \& Wilbraham (1939), of him sitting on a chair suspended from a steelyard with a meal in front of him. He was recording his weight before and after eating, and his loss in weight between meals that could not be accounted for by urine and faeces; this he termed 'insensible perspiration'. It included loss of water by respiration. Sanctorius assumed that all the loss of weight was due to loss of water, for nothing was known at that time about the gas exchanges of the body.

\section{WILLIAM STARK. AN 18TH-CENTURY SELF-EXPERIMENTER}

We owe it to the late Sir Jack Drummond and Anne Wilbraham for the story of the selfexperimentation of a young doctor, William Stark, in the eighteenth century (Drummond \& Wilbraham, 1935). He received his medical education at St George's Hospital, London and Leyden University, Holland. He then returned to London to work under John Hunter. There were various stories going around at that time about individuals who had lived healthy lives while having very simple and restricted diets. Stark decided to investigate this on himself. His choice of diet was probably influenced by Benjamin Franklin, an American doctor, who told Stark that he himself had lived on bread and water for a fortnight, eating $10 \mathrm{lb}$ bread a week, and found himself 'stout and hearty' at the end of it.

Stark was then 29 years old and $12 \mathrm{st.} 3 \mathrm{lb}(76 \mathrm{~kg})$ in weight. His first experiment began in June 1769 and he started by following Benjamin Franklin's example and living on bread and water for 10 weeks, with a little sugar in addition for 2 of the weeks. His ration of bread at the beginning was $20 \mathrm{oz}(568 \mathrm{~g})$ a day, which would have provided him with $1220 \mathrm{kcal}$ $(6.08 \mathrm{MJ})$. Not surprisingly he was hungry and lost weight, so he increased his daily allowance to $30 \mathrm{oz}(852 \mathrm{~g})$ and then $38 \mathrm{oz}(1079 \mathrm{~g})$, providing $1830 \mathrm{kcal}$. $(7.66 \mathrm{MJ})$, and $2320 \mathrm{kcal}(9 \cdot 71 \mathrm{MJ})$. Drummond \& Wilbraham (1935) surmised that at that period the bread would have been made from wholemeal wheaten flour. Stark developed symptoms of scurvy, sore and bleeding gums, and felt rather ill. However he soon recovered on 'animal food, milk and wine'.

His next diet, which he ate for a month, consisted of 'puddings' made of flour, various fats and water. Some of the fats caused intestinal problems and again Stark developed scorbutic symptoms, which even half a pint of blackcurrants, later shown to be a rich source of vitamin C (Olliver, 1940), did not cure. He knew that meat was in some way beneficial, so he then tried to find out which was the more nutritious, the fat or the lean. He again had digestive problems on the high fat diets, possibly due to rancidity of the fat. The plan was to follow this by adding fruit and green vegetables to his diet. Had he done this all would have been well. Unfortunately he changed his mind and decided instead to make a study of the food value of honey pudding and Cheshire cheese. It is not clear exactly what the honey pudding consisted of, but in any case neither of these foods would have provided vitamin $\mathrm{C}$. He already had an intestinal infection, his scorbutic symptoms became worse and he died in February 1770.

It seems rather surprising now that Sir John Pringle, who had befriended Stark in his student days and had been instrumental in his going to Leyden, did not come to the rescue. Pringle was interested in scurvy and was in touch with Captain Cook over his endeavours to find some food or medicine that could be carried on ships at sea for long periods, which would prevent scurvy among the sailors. Cook, in his voyage round the world (1772-3), kept his men free from scurvy by including fresh fruit and vegetables in their diet (Bicknell 
\& Prescott, 1946). However, Pringle seems to have been obsessed with the idea that too much salt in the diet was the cause of the disease, and the only advice he gave Stark was to omit salt from his diet (Drummond \& Wilbraham, 1935).

\section{THE PROTEIN REQUIREMENT OF MAN}

The famous German scientists who laid the foundation of the science of nutrition in the second half of the 19th century, Rubner, Voit, Bischoff, Pettenkofer, Liebig and others, made many studies on man as well as dogs, but there is little evidence that they used themselves as subjects for their experiments. They were concerned with gas exchange and energy metabolism and the energy value of foods and faeces. They also set out some values for man's requirement for protein, but these were based, not on experiment, but on observation of the amount of protein in the diet of labourers at that time (Lusk, 1928). This was about $120-130 \mathrm{~g}$ a day, and protein provided $15 \%$ of the energy value of the diet.

\section{SIVÉN AND CHITTENDEN: REQUIREMENT FOR PROTEIN ON A MIXED DIET}

A 30-year-old Scandinavian physiologist, Sivén (1900, 1901), appears to have been the first to put protein requirement to the test. After some preliminary studies he started an experiment on himself in November 1897. There were four weekly periods. The food provided $12 \cdot 7,10 \cdot 4,8 \cdot 7$ and $6.3 \mathrm{~g}$ nitrogen a day, equivalent to $79,65,54$ and $39 \mathrm{~g}$ protein a day respectively. The diet was 'rich in carbohydrates' and provided $2444 \mathrm{kcal}$ (10.2 MJ) a day. It was only on the lowest protein intake that Sivén was in negative nitrogen balance. A year later Sivén (1901) made another experiment on himself when he consumed a diet containing even less nitrogen (4-5 g) but more carbohydrate and more energy $(2700 \mathrm{kcal}$, $11.3 \mathrm{MJ}$ a day). On this he was in nitrogen balance. These experiments were criticized by the German scientists because each study had lasted for only a short period and it was strongly believed that more protein than Sivén had taken was necessary to maintain health and strength over a longer period of time. Strangely, the evidence for this seems to have come from older experiments on a carnivore - the dog. Rubner stated that a large protein allowance was 'the right of civilized man...' (Lusk, 1928).

Then Chittenden, an American physiologist, became interested in the requirement for protein (Chittenden, 1904). He could not understand why adults, who were not using protein for growth, should need so much protein in their diet. He was suffering from rheumatism of the knee joint and he decided that a diet containing less protein and providing less energy than his normal one might do him good. His diet provided $1550-1600 \mathrm{kcal}(6 \cdot 5-6 \cdot 7 \mathrm{MJ})$ a day and 5.9-6.4 g N (37-40 g protein), which was less than half as much as had been considered necessary. Urinary nitrogen was determined daily and averaged $5.7 \mathrm{~g}$ at the beginning and $5.4 \mathrm{~g}$ at the end of the 9 months of the experiment. Faecal losses of $\mathrm{N}$ were reckoned to be about $1 \mathrm{~g}$ daily. Professor Chittenden lost weight at the beginning of the study, but after 8 months his weight remained steady. The rheumatic trouble disappeared and he felt fit and healthy.

Chittenden made similar studies on 5 professional men, 8 university athletes and 13 soldiers. Energy intake was not restricted but the diet contained considerably less protein than that to which the men were accustomed. They maintained nitrogen equilibrium on diets providing 46,50 , and $49 \mathrm{~g}$ protein a day for professors and teachers, athletes, and soldiers respectively. Chittenden became a great advocate of low protein diets, and his book (Chittenden, 1904) entitled 'Physiological economy in nutrition' sets out his views. 
Another Scandinavian, Hindhede (1913), also became a protagonist for a low protein diet. He had proved its effectiveness on himself, but he also believed in a simple 'back to nature' diet of wholemeal bread, potatoes, apples, vegetable margarine and milk.

The studies of Siven and Chittenden were made before anything was known of the biological value of different proteins, or of the importance of eating a variety of foods if the diet is largely vegetarian. More recent work has shown that if energy and all other nutrients are present in adequate quantities then the amounts of protein recommended by Sivén and Chittenden, against much opposition, do represent the requirements of adult man. The figures proposed by the Panel on Dietary Reference Values (1991) for protein are close to those arrived at by self-experimentation 90 years ago.

\section{MARTIN AND ROBISON. THE BIOLOGICAL VALUE OF PROTEINS}

The diets eaten by Sivén and Chittenden contained a mixture of proteins from plant and animal sources. In 1922 a paper was published by Martin \& Robison, working at the Lister Institute, London, describing their nitrogen balance studies on themselves when their diet contained only one source of protein. By these means they hoped to compare the biological value of proteins from different sources. 'CJM' was then 56 years old and ' $R R$ ' 37 . Both worked in the laboratory and they continued to live their usual lives during the experiments.

They started with a diet as nearly nitrogen free as possible. Their food consisted of very hard biscuits made from starch, dextrin and a little fat, and these were spread with butter and honey. A mould made from starch and flavoured with lemon juice provided some variation. Drink consisted of weak tea with lemon, or black coffee with a little vermouth. "After the first few days of this diet no desire was felt either for this or for any other food, nor did the sight of our first normal meal at the close of the experiment arouse any appetite. The drinking of a glass of hot milk, however, excited in a few minutes a very keen appetite and desire for food" (Martin \& Robison, 1922).

In spite of their loss of appetite Martin \& Robison forced themselves to eat sufficient of the diet to provide them with approximately $3000 \mathrm{kcal}(12.6 \mathrm{MJ})$ a day. There were two periods, each lasting for 7 days (RR's first period lasted for 6 days) with an interval of 9 days on a normal diet in between. The diet provided $0 \cdot 2-0 \cdot 3 \mathrm{~g} \mathrm{~N}$ (equivalent to $1 \cdot 3-1.9 \mathrm{~g}$ protein) a day and their urinary excretion of $\mathrm{N}$ fell in a regular manner, reaching a daily minimum of about $2 \mathrm{~g}$ in 5-7 days. Their negative nitrogen balance during the last 3 days of each period was about $3 \mathrm{~g}$ a day.

In the second experiment whole wheat bread provided the source of protein, and the nitrogen intake was $12 \mathrm{~g}$ a day (equivalent to $75 \mathrm{~g}$ protein). This experiment lasted for 35 days, and the biological value of the wheat protein calculated according to the following two alternative formulae was about $30 \%$.

$$
\begin{aligned}
\text { B.V. }=\frac{\text { Balance }(P)-\text { Intake }(M)-[\text { Urine } N(M)+\text { Faeces } N(P)]}{\text { Intake }(P)-\text { Intake }(M)} \times 100 & \text { Eqn (1) } \\
\text { B.V. }=\frac{\text { Balance }(P)-\text { Balance }(M)}{\text { Intake }(P)-[\text { Faeces } N(P)-\text { Faeces } N(M)]-\text { Intake }(M)} \times 100 & \text { Eqn (2) }
\end{aligned}
$$

where $\mathrm{M}=$ first minimum nitrogen diet, $\mathrm{P}=$ second bread diet. Both men were in slight negative nitrogen balance on the bread diet.

An experiment with milk as the sole source of protein followed, the rest of the diet consisting of starch, lactose, sucrose, honey, and margarine, with tea to drink. Both Martin and Robison lost weight and were in negative nitrogen balance on this diet because they 
found it difficult to consume enough milk to keep up their energy intake. Martin then repeated the experiment, for two periods of 10 days, forcing himself to increase his energy intake. A 'bilious attack' made him discontinue the experiment. However, from the results that were obtained it was calculated that the biological value of the proteins of cows' milk was $51 \%$.

The authors conclude that "Biological values arrived at from experiments of comparatively short duration, however well justified, have a limited significance". The periods may have been short, but the results of Martin and Robison, obtained from experiments on themselves, for the biological value of the proteins of cow's milk and whole wheat bread were in very much the same proportion to each other $(51 / 30=1 \cdot 70)$ as those later derived from the amino acid score, calculated from the amino acid composition of the proteins $(95 / 53=1.79)$ and for the net protein utilization of the proteins from the two sources obtained from experiments on rats $(82 / 48=1 \cdot 71)$.

\section{THE UNRAVELLING OF THE FUNCTION OF THE VITAMINS}

\section{JOSEPH AND MARY GOLDBERGER. SELF-EXPERIMENTATION AND THE CAUSE OF PELLAGRA}

In the early years of the 20th century pellagra, which was then thought to be an infectious disease, was spreading like an epidemic through the United States. A Pellagra Commission was created by Congress and Joseph Goldberger, a member of the U.S. Public Health Service, was put in charge. He already had experience of epidemics, and also of selfexperimentation, for in 1909 he had discovered the cause of Schemberg's disease by tracing the infestation to tiny insects in the straw used for mattresses. After he had begun to suspect the mattresses, he tied some of the straw round his arm and shoulder. Sure enough, the characteristic itching eruption began.

Goldberger knew nothing about pellagra, and his first idea was that it was caused by poor hygiene. However, he was impressed with the fact that in institutions where pellagra was common among the patients it did not occur among the doctors and nurses who attended them. This made him think that infection was unlikely to be the cause, and that the disease was probably due to a faulty diet. He tested this by giving the children in one ward of an orphanage extra eggs, milk, beans, peas, oatmeal and meat in their diet. Pellagra disappeared in this ward, but not in another where no extra food was supplied.

Goldberger then set out to prove that poor nutrition was the sole cause, and that infection was not involved. In 1916 he and a fellow doctor, George Wheeler, injected into the shoulder of each other blood taken from a patient with a first attack of pellaga. Nothing happened. Then they rubbed secretions taken from the nose and mouth of the pellagra patient into each other's nose and mouth. Again nothing happened. Finally Goldberger swallowed capsules containing urine, faeces and skin taken from patients with severe pellegra. He had some diarrhoea after this, but no pellagra. A short time later this was repeated on himself, and on five others including his wife Mary. She had insisted on this in order to represent women in the experiments - a rarity in the history of selfexperimentation (Goldberger, 1956). None of them developed pellagra. These 'filth parties', as Goldberger called them, were repeated twice more. All the subjects remained healthy, proving that pellagra was not an infectious disease (Sydenstricker, 1958).

Goldberger still did not know what constituent of the food was responsible for preventing pellagra, and it was more than 20 years later that Elvehjem and co-workers (Elvehjem et al. 1937, 1938) showed that a deficiency of nicotinic acid was the cause of pellagra in man as well as of black-tongue in dogs. 


\section{JOHN CRANDON. SCURVY AND VITAMIN C}

Several authors who have written about the history of scurvy and vitamin $C$ have given vivid accounts of the self-experimentation of John Crandon. These include Drummond \& Wilbraham (1939), Carpenter (1986) and Altman (1987). Crandon qualified in medicine in USA in 1937. Two years later he was assistant surgeon to Dr Charles C. Lund at the Boston City Hospital. Dr Lund was interested in the function of vitamin $C$ in the body, particularly its relation to wound healing. His enthusiasm inspired Crandon, who planned an experiment in which three individuals, of which he himself would be one, would eat a diet containing no vitamin $\mathrm{C}$. This seemed to present no danger since the remedy was known and at hand, and the plan was approved by $\mathrm{Dr}$ Lund. The concentration of vitamin $\mathrm{C}$ in the blood would be followed, and when this reached very low levels and signs of scurvy appeared deep incisions would be made in the skin and muscle, and the progress of healing would be observed.

As was the custom in the United States, 'volunteers' for scientific experiments had to be paid, but no funds were available. An aunt of John Crandon, a missionary, offered to hire two teenagers from poor families who she knew would be glad of the money. The three subjects started the experiment in October, 1939. The diet consisted of well cooked meat, butter, polished rice, cake without any fruit, and coffee. However, after three weeks the two young 'volunteers' were caught drinking orange juice in a cafeteria, so the study on them was abandoned, and Crandon carried on alone. After two months he varied his diet with cheese, crackers, eggs, and candy bars; he took supplements of all vitamins except C. After 41 days plasma ascorbic acid had fallen to zero (Crandon \& Lund, 1940), but it was only after 82 days that the ascorbic acid in the white cell/platelet layer of centrifuged blood became zero. The first clinical evidence of deficiency was the appearance of hyperkeratotic papules after 132 days. Perifollicular haemorrhages occurred after 161 days. After 3 months on the diet a 3-inch-long incision was made in Crandon's back, but a biopsy taken 10 days later showed that the wound was healing normally. This was disappointing, but Crandon continued with the diet. All this time he carried on the his surgical work at the hospital. He began to feel very tired and his work suffered. Dr D. B. Dill, at the Harvard Business School, was at that time studying fatigue, so he put Crandon on his treadmill to get some quantitative measure of his tiredness. Crandon was told to run as fast as he could, but after a short time he collapsed and became unconscious (Crandon et al. 1940). This was undoubtedly a result of his state of vitamin $\mathrm{C}$ deficiency, and sudden deaths among seamen with scurvy had been reported many years before by Lind (1753). Crandon recovered from this episode, and after 6 months on the diet he insisted on having another incision made down his back. This time there was no evidence of healing.

This was a heroic effort of one man to follow the development of scurvy. It has been described as "the only complete experiment on the production of scurvy on a human being" (Sydenstricker, 1953) and "the classic experiment" (Wolbach, 1953). It demonstrated that very low or even zero concentrations of vitamin $C$ in plasma did not necessarily indicate the presence of clinical scurvy, and that it took much longer than had been supposed to produce scurvy in a previously well nourished man.

\section{VICTOR HERBERT. FOLIC ACID DEFICIENCY}

Twenty years after John Crandon's self-experimentation in which he produced vitamin $C$ deficiency another young American doctor, Victor Herbert, came to work at the same place, the Thorndike Memorial Laboratory at the Boston City Hospital. Herbert had received his medical education at Columbia University, New York; he had then spent some 
time at the Walter Reed Army Medical Center, Washington, and served as an army medical officer in Germany. When he returned he worked at several hospitals in New York, and became interested in megaloblastic anaemia due to folic acid deficiency. At that time (the late 1950s) folic acid (or folate) deficiency was considered to be a rare disorder due to a complicating problem such as alcoholism or malabsorption. Herbert believed that a deficient diet could of itself produce folate deficiency and he with others developed a test for the measurement of folate in blood (Baker et al. 1959). When he was offered an appointment at the Thorndike Memorial Laboratory in Boston, to work under the world famous William Castle, he accepted at once. As Altman (1987) says, "to work with Castle at the Thorndike was one of the most valued opportunities in the world". Castle was well known for his studies on pernicious anaemia. Many years earlier he had used himself to prove that there was something secreted by the stomach of a normal person that was not secreted by a patient with pernicious anaemia. This substance, which he called the 'intrinsic factor', and was later shown to be a protein, is necessary for the maximum utilization of the 'extrinsic factor', later identified as vitamin $B_{12}$.

Herbert's belief that folate deficiency leading to megaloblastic anaemia could be produced by a faulty diet alone was confirmed when he saw a patient who was suffering from both scurvy and megaloblastic anaemia resulting from folate deficiency (Zalusky \& Herbert, 1961). The man had for the past 5 years since his retirement lived exclusively on food obtained at fast-food stands, and his diet had consisted entirely of cheap hamburgers, doughnuts and black coffee. Herbert realized that this one patient was not sufficient to prove that his idea was correct, so he decided to do what Castle and Crandon had done before him and use himself as the subject of an experiment in which he would eat a diet devoid of folate until he developed megaloblastic anaemia. The folate content of foods was at that time not known in any detail, so analyses were made on raw foods and on the same after repeated boiling to remove all the folate. The experiment began in October 1961, just 22 years after Crandon's. A description of it is given by Herbert (1962) and by Altman (1987) who interviewed Dr Herbert on several occasions. All raw food was excluded from the diet, and all animal food, vegetables and fruit were boiled several times over and the water discarded. In spite of the generous use of salt, pepper, Worcester sauce and monosodium glutamate Herbert found the diet unpalatable, and he lost $26 \mathrm{lb}(11.2 \mathrm{~kg})$ in weight during the experiment. Blood was collected every day for the determination of folate and for the production of new red blood cells. A sample of bone marrow was taken from time to time, which, for Herbert, was a rather painful procedure.

Most of Herbert's colleagues (especially Castle) approved of what he was doing, but one of them strongly disapproved, saying that doctors should not experiment on themselves.

After Herbert had been on the diet for about 8 weeks he began to feel rather tired and then, on Christmas morning, after his wife had gone out, he found that he could not get out of bed. He first thought that this paralysis must be due to folate deficiency, though it was not an effect he had expected. However, it occurred to him that the repeated boilings of his food would have removed not only folate, but also potassium, and the paralysis was much more likely to be due to potassium than folate deficiency. He had some samples of potassium salts sent to him by drug companies in a drawer near his bed, so he took a generous dose of potassium iodide. He was soon able to get out of bed and, though still weak, he drove himself to the hospital. Although it was Christmas day he found one colleague there who took a sample of blood, but there was no-one to analyse it. When finally this was done the serum potassium was indeed found to be very low, even though he had already dosed himself with potassium iodide. With larger doses of potassium the weakness disappeared and Herbert recovered completely.

This incident, like Crandon's on the treadmill, demonstrates that self-experimentation is 
not without danger, and how important it is that the subject himself, and someone close to him, should be trained observers, understanding what is going on, and be ready for unexpected events which might endanger the subject's life.

Herbert continued with his diet, supplemented with potassium, for a total of 19 weeks. At this stage he was found to have mild megaloblastic anaemia. He had proved that his hunch was correct, and he discontinued the experiment. The analysis of the blood and bone marrow samples collected throughout the experiment enabled Herbert and his colleagues to reconstruct the changes in his body that had taken place as the folate deficiency and megaloblastic anaemia developed.

\section{DEFICIENCIES OF ELECTROLYTES AND WATER}

\section{R. A. MCCANCE. EXPERIMENTAL SODIUM CHLORIDE DEFICIENCY}

While self-experimentation involving deficiencies of vitamins was going on in the United States, studies by physicians on themselves to investigate the effects of deficiencies of electrolytes were being made in Britain. The pioneer was R. A. McCance. He had studied physiology at Cambridge under Sir Joseph Barcroft, and obtained his Ph.D. in biochemistry under Sir Frederick Gowland Hopkins before going to King's College Hospital, London in 1926 to complete his medical training. While still a medical student he assisted Dr R. D. Lawrence in the new diabetic clinic, and became interested in diabetes and particularly in the complications of diabetic coma. The high blood sugar causes a forced diuresis, and there is also a loss of sodium and chloride from the body. The salt deficiency in diabetic coma is, however, complicated by the activity of insulin, an acidosis and other metabolic abnormalities. Salt deficiency is also a complication of severe vomiting.

After he qualified in medicine in 1928 McCance remained at King's College Hospital, and in the early 1930s was in charge of the new clinical biochemistry laboratory. His interest in the effects of uncomplicated salt deficiency remained, reinforced by observations on the disabling effects of sweating among men during heavy work in hot atmospheres when they had unlimited access to water. He decided to produce sodium chloride deficiency in himself, and to study its physiological effects. If all went well he would then ask for volunteers among the medical students so that the experiment could be repeated. In the event 5 more experiments were made (McCance, 1936a,b).

The salt deficiency was produced by eating a salt free diet and sweating. The salt free diet was unpalatable, but McCance persevered in eating it, and found sweet foods more palatable than savoury ones. The sweating took place in a full length metal tunnel fitted with lamps at intervals along the inside of the top. This was placed over a mattress with two pillows on the floor, over which was spread a red rubber sheet. The lamps were switched on about half an hour before he entered, naked, and he lay there for two hours every afternoon for 10 days, sweating profusely, but drinking as much water as he could and taking his temperature at intervals. Ten minutes before he emerged the lights were switched off so that he could cool off slowly. He then crawled out and stood in a tub while a colleague washed him down head to foot into the tub with a jet of distilled water. Sweat was bailed off the sheeting, which was then lifted up and washed into the tub with a jet of distilled water. Insensible perspiration was collected from the washings of underclothes previously washed in distilled water, and combined washings were evaporated down for analysis. All urine and faeces were collected for analysis.

He lost about $30 \%$ of his body's sodium and chloride. There was an obvious change in his appearance. The temporal hollows and cheeks fell in and the eyes looked tired and sunken. There was a loss of weight, and anorexia and nausea were prominent symptoms. 
He suffered considerably from cramps, and any muscle might suddenly be affected. He was mildly breathless at first, but later there was general exhaustion and distress at the least exertion. At the beginning of the experiment he walked a mile every day; towards the end he still went on the walk, but had to sit on a wall and rest several times on the way.

Tests showed that the body subjected to salt deficiency of this magnitude suffered decreases in the concentrations of sodium in serum and other extracellular fluids, and in the fluid volumes.

Even when he was severely salt deficient McCance's curiosity never left him. He knew that in pyloric stenosis and after persistent vomiting for other reasons patients have both an alkalosis and a sodium chloride deficiency. Their urines, which should be alkaline because of the alkalosis, are acid because of the sodium deficiency. He wanted to reproduce this in himself; he was already sodium deficient but he had to produce an alkalosis. He did this by overbreathing and so removing carbonic acid from his body. The response of a normal person to an alkalosis brought about by overbreathing is to secrete an alkaline urine. When he was salt deficient, however, the $\mathrm{pH}$ of his urine after overbreathing did not change. There was an 'untoward incident' after one of his $45 \mathrm{~min}$ overbreathing sessions, for his body fluids had become so alkaline that there was no stimulus to his respiratory centre to make him start to breathe normally after he stopped overbreathing. He became unconscious for several minutes and did not recover completely for several hours. Fortunately he did recover to live another 60 years.

\section{A. K. BLACK AND M. D. MILNE; PAUL FOURMAN. EXPERIMENTAL POTASSIUM DEPLETION}

Twenty years after McCance's studies on experimental sodium chloride deficiency Douglas Black and M. D. Milne in Manchester and Paul Fourman in Oxford set out separately to produce potassium deficiency in themselves. Their interest arose from the effects of the depletion of potassium that arises as a complication of gastroenteritis, Cushing's syndrome and other disorders. Potassium, the intracellular cation, is more difficult to remove from the body than the extracellular eletrolytes sodium and chloride. Black and Milne's method of making themselves potassium deficient was to consume daily 31 milk which had been run through a column of Zeocarb $225 \mathrm{Na}$ containing $500 \mathrm{~g}$ cation exchange resin. This reduced the concentration of potassium in the milk from 43 to 4 mequiv./1. Glucose $(125 \mathrm{~g})$ was added to the daily quota of milk and the experiment lasted for 7 days (Black \& Milne, 1952). There were no dramatic effects, and both self-experimenters remained at work. They felt rather apathetic, but there was no obvious muscle weakness which is characteristic of severe potassium deficiency (see p. 8). There was some loss of potassium and of intracellular fluid from the body and a gain in extracellular fluid. The serum potassium was decreased, but it was concluded that the deficiency was not enough to produce symptoms.

Paul Fourman's study was made a short time later (Fourman, 1954). He and another subject, a woman, induced potassium deficiency in themselves by swallowing a polystyrene exchange resin in a hydrogen form. They continued for 16 days, and the potassium depletion and its effects were more severe than those in the study of Black and Milne. Fourman and his colleague became mentally confused, and suffered from weakness, anorexia and apathy. Because their resin was in the $\mathrm{H}$ cycle and not in the $\mathrm{Na}$ cycle like that used by Black and Milne they had acidosis as well as potassium depletion and it seems likely that it was the combined effect that was the cause of the more severe symptoms. About $2 \%$ of the body's potassium was lost. The serum potassium fell and that of sodium rose. Retention of sodium led to expansion of the extracellular fluids and entry of sodium into cells. Fourman contrasted the effects of deficiencies of sodium and potassium; sodium 
depletion causes a decrease in the volume of extracellular fluids but little change in serum sodium, whereas in potassium depletion the changes in the volume of intracellular fluid were slight but the change in composition was comparatively large. Recovery was rapid when potassium was restored.

\section{A. K. BLACK AND R. A. MCCANCE. WATER DEPLETION}

For a period during the early 1940s D. A. K. Black worked in the Department of Experimental Medicine, Cambridge with R. A. McCance. This was after McCance's studies on experimental sodium deficiency and before those of Black on deficiency of potassium. Both were interested in the water turnover of the body, and particularly in the effects of dehydration. The prevention of this is important in diseases where there is excessive loss of water, and it was of special concern during the Second World War when a shortage of water was a severe hazard among soldiers isolated in hot deserts, and shipwrecked mariners aboard life boats or life rafts who might not be rescued for many days. Black and McCance decided to investigate the changes in body fluids and electrolytes when normal persons were deprived of fluids to drink and ate food containing minimal amounts of water (Black et al. 1944).

A preliminary experiment was made on McCance to study the general features of dehydration and especially the function of the kidneys. This was followed by the main experiment on Black and a colleague. Black's diet consisted of brown bread, butter, marmalade, cheese, dates, meat paste, shortbread, oatcakes and toffee. For the first 4 days they ate the diet with as much water, tea or coffee as they desired. For the next 3 or 4 days they ate the same diet but had nothing to drink. The experiment concluded with 3 days on the same diet with measured amounts of water.

During the period of dehydration Black lost $3.8 \mathrm{~kg}$ weight and his negative water balance was $3.5 \mathrm{~kg}$. Neither he nor his colleague were unduly thirsty, but their throats were dry, their voices husky and they found difficulty in swallowing the dry food. Their faces looked pinched and pale and there was some cyanosis round the lips. This general appearance of illbeing vanished within a few hours of the restoration of water.

Measurements of the body fluids and electrolytes showed that during dehydration there was no reduction in plasma volume, but a rise in osmolarity and concentration of sodium. There was also an increase in the production of urea. Renal function remained normal, and the urine was maximally concentrated.

They concluded that the increase in osmolarity of the body fluids is a likely cause of death due to dehydration. It was therefore important that rations designed for soldiers and sailors who might be stranded without fresh water should contain only very small amounts of salt and protein to minimize the sodium and nitrogen requiring to be excreted. Later investigations (Hervey, 1957) carried this recommendation further by emphasizing that those aboard life rafts after shipwreck with only small supplies of fresh water should never drink sea water, for this has an osmolar concentration considerably greater than that of maximally concentrated human urine, and it would accentuate rather than relieve the effects of dehydration.

\section{THE EXCRETION OF IRON, CALCIUM, MAGNESIUM AND STRONTIUM}

In this section I describe some of my own personal experiences of self-experimentation. They were made in collaboration with Dr R. A. McCance in the 1930s, during the first 5 years of our 60 -year scientific partnership. They were not as dramatic as some of the 
experiments described, but they taught me much about the ethics of making studies on human beings, from the point of view of both experimenter and experimentee.

\section{MCCANCE AND WIDDOWSON. THE EXCRETION OF IRON AFTER INTRAVENOUS ADMINISTRATION}

Our interest in the excretion of iron was aroused in 1936 when a patient, Mrs Harris, aged 61, was admitted to King's College Hospital suffering from polycythaemia rubra vera. Her blood count on admission was 10.9 billion per $\mathrm{ml}$ and her cell volume $87 \%$. She was given a diet containing 3-4 mg iron a day for 6 days, and during the last 3 days urine and faeces were collected. Then she was treated with acetyl phenylhydrazine for 14 days, which brought about a rapid destruction of her excess red cells, and this continued after the treatment stopped. We calculated that more than $6 \mathrm{~g}$ iron were set free inside her body from the broken down red cells. Collections and analysis of urine and faeces continued, but, to our surprise, there was no increase in faecal or urinary excretion of iron (McCance \& Widdowson, 1937). Up to that time it had been taught that the amount of iron in the body was regulated by controlled transfer of iron to the intestine and so to its excretion. We decided that we must investigate this further by giving ourselves an iron salt by vein and following our iron excretion. Four colleagues joined us, and the six of us ate a diet providing about $7 \mathrm{mg}$ iron a day for 14 days and our intake and excretion of iron were measured. Then, continuing on the same diet, we increased our daily iron intake to $14 \mathrm{mg}$ by taking by mouth a solution of ferric ammonium citrate. In both periods we were in iron balance. The urinary excretion was very low, averaging about $0.1 \mathrm{mg}$ a day, and the faecal excretion corresponded to the intake. Still on the same diet we gave ourselves and our colleagues $7 \mathrm{mg}$ iron a day as ferric ammonium citrate intravenously for 14 days, and we found again that there was no increase in iron excretion (McCance \& Widdowson, 1938). This confirmed the conclusions we had drawn from the study on the patient that the intestine plays no part in regulating the amount of iron in the body, and that this is normally regulated by controlled absorption.

\section{MCCANCE AND WIDDOWSON. THE FATE OF CALCIUM AND MAGNESIUM AFTER INTRAVENOUS ADMINISTRATION}

These studies were made at the same time as those on iron (McCance \& Widdowson, $1939 a$ ). Just as it used to be believed that iron was actively excreted by the intestine when there was an excess in the body, the same idea was held about the divalent elements calcium and magnesium. However, by 1937 when our studies on iron were being made, evidence was forthcoming suggesting that this was not the case. We therefore decided to investigate the absorption and excretion of calcium and magnesium as well as of iron. As with iron, the intake and urinary and faecal excretion of the two elements was measured for 14 days at two levels of intake. Then solutions of calcium and magnesium gluconates were injected every day for a fortnight with a home-made 'Heath-Robinson' type of apparatus which is illustrated in Widdowson (1980). The injections took about 30-45 minutes, and with a little practice we managed to do this for ourselves. Our only trouble was the rather unpleasant hot flushes when the calcium went in.

The results showed that intravenous injection of calcium and magnesium gluconate resulted in no increased excretion by the intestine, but they were both rapidly excreted in the urine, showing how sensitive the kidney is to changes in the concentrations of calcium and magnesium in the serum. As in the case of iron, the intestine does not regulate the amount of calcium and magnesium in the body. 


\section{MCCANCE AND WIDDOWSON. THE FATE OF STRONTIUM AFTER INTRAVENOUS ADMINISTRATION}

After we had moved to Cambridge in 1938 we made a similar study on ourselves with strontium (McCance \& Widdowson, 1939 b). Strontium had been used medicinally for a long time for a variety of diseases, and it had been given by both mouth and vein. However, little or nothing was known about its excretion, so we designed an experiment to find something out about this. There was to be a preliminary period of 7 days during which our intake and urinary and faecal excretions of strontium were measured. Then, for a further 7 days, intake and excretion of strontium would continue to be measured while we received in addition a solution of strontium lactate by vein. The following is Professor McCance's description of what happened (McCance, 1993). "We started on a Monday with my injecting $23.5 \mathrm{mg}$ strontium as strontium lactate into a vein in Elsie's arm. Nothing happened after 24 hours, so we decided to double the dose to $47 \mathrm{mg}$. On Tuesday I took my first dose. For the next 5 days we carried out our scheme without problems. But by Friday we had used up the batch of sterilised strontium lactate solution, and had to sterilise some more.

"At eleven on Saturday morning, the sixth day of the experiment, we injected the prescribed dose into each other's arms. We had become over-confident, one of the biggest hazards of self-experimentation. During the week someone had always stood by, but because nothing had happened we carried on alone. Less than an hour later we began to feel ill. We suffered intense headaches and teeth-chattering rigors. Our backs and thighs hurt. We felt dreadful and did not know what had gone wrong and were apprehensive.

"Fortunately, someone came by and called John Ryle, the Regius Professor, who rushed to the laboratory. After realising that our lives were not in immediate danger, Ryle took us home with him where he and his wife could look after us. By this time about 4 hours had passed, and both of us had developed fevers of $102^{\circ}$. Despite feeling ill, we had still managed to collect the samples we needed. Later, analysis showed that pyrogens due to bacterial contamination were present in the second batch of strontium lactate. We had suffered a pyrogen reaction. We recovered quickly but gave each other no further injections. The results of the experiment showed that the body rids itself of strontium slowly, and that about $90 \%$ of the excretion is by the kidney."

\section{THE DIET OF THE ESKIMO AND THE IMPORTANCE OF POLYUNSATURATED FATTY ACIDS}

\section{HUGH SINCLAIR. A LONE SELF-EXPERIMENTER OF THE 1970s}

Hugh Sinclair (1910-1990) spent most of his life at Oxford. After leaving Winchester school he went to Oriel College where, in 1932, he graduated with first class honours in Physiology and, in 1937, in Medicine, after receiving his medical training at University College Hospital, London. He was elected a Fellow of Magdalen College, Oxford, and appointed Lecturer in Physiology and Biochemistry in the University. He particularly admired the work of Dr Cicely Williams, Sir Robert McCarrison and Vilhjalmur Stefansson. All three were lone workers, as indeed was Sinclair himself. Dr Cicely Williams was medical officer at the Princess Marie Louise Hospital at Accra in the Gold Coast Colony in the late 1920s and early 1930s. She saw and described a disease in young children which she attributed to a deficiency of protein in their diet and which she called kwashiorkor. Sir Robert McCarrison lived for 7 years with the Hunza, a tribe inhabiting a fertile area in the north of India, who ate a varied diet consisting largely of plant foods. They rarely developed the 
degenerative diseases of the Western world and many of them lived to a great age. By way of contrast were Stefansson's observations on the Eskimo.

Stefansson was of Scandinavian ancestry, but was born in Manitoba, and was educated at the State University of Iowa and at Harvard. He was an explorer, going on many expeditions, particularly to the Arctic, and he commanded the Canadian-Arctic Expedition of 1913-18. He lived with Eskimos for periods between 1906 and 1918, and observed that their diet consisted entirely of seal meat and fish; it was therefore rich in protein and fat and contained very little carbohydrate. In spite of this the Eskimos, like the Hunza, suffered little from Western diseases, and the incidence of cardiovascular disease was low. Stefansson shared the Eskimo diet while he was living with them, and he remained in good health (Stefansson, 1956a). In 1928 he and a colleague lived for a year on a diet of meat and water. While eating fatty meat for many months they remained well and showed no signs of scurvy but when their only food was lean meat they soon became ill (Stefansson, $1956 \mathrm{~b}$ ). Sinclair was intrigued by Stefansson's observations, and particularly by the Eskimo's high intake of fat. With the help of a Radcliffe travelling scholarship he went to USA in 1937 and visited George Burr and his wife, who had recently shown that rats did not grow or reproduce satisfactorily on a diet that was deficient in linoleic or linolenic acids, which they had called 'essential fatty acids'. This visit was the spark that set off Sinclair's determination to devote himself to the study of the function of lipids and fatty acids, and the effects of a deficiency of 'essential fatty acids' on the human body.

During the Second World War, while working on behalf of the Royal Canadian Air Force, Sinclair had the opportunity of comparing the deposition of cholesterol in the eyes (corneal arcus) of Eskimos and young British pilots. The Eskimos, young and old, show no sign of the disorder, whereas $10 \%$ of the young Britons were affected. Sinclair suggested that the difference was due to difference in diet, the lipids of the marine food of the Eskimos containing far more of the essential fatty acids than that of the Britons, and this prevented the cholesterol deposition (Garton, 1990).

In spite of many frustrations Sinclair's great interest in the role of the polyunsaturated fatty acids in the human diet never left him. He was in touch with some Danish investigators, Bang and Dyerberg, who had paid two visits to Eskimos living in NW Greenland, and they invited him to accompany them on a third expedition. He spent two weeks making detailed dietary studies and clinical examinations. Unfortunately the weather became worse and he was not able to make the measurements he had planned during a third week on bleeding times and other tests. He could not raise funds to go again.

In 1979 he decided that he would himself live on a traditional Eskimo diet for 100 days, and have the tests made on him that he had been unable to make on Eskimos in Greenland. He hoped that the results would clarify the relation between the polyunsaturated fatty acids and coronary heart disease. He obtained a frozen seal from a seal cull, bought large numbers of cans of fish and fish products and ordered a supply of fresh fish. Starting in March 1979 he lived entirely on these foods for 100 days, with only water to drink. All foods eaten were weighed, and portions analysed for fat, fatty acids, and for vitamins $A$ and C. From these values the intake of nutrients was calculated. A typical day's diet consisted of:

Breakfast $530 \mathrm{~g}$ smoked haddock

Lunch $212 \mathrm{~g}$ salmon (canned)

$142 \mathrm{~g} \mathrm{crab}$

Dinner $120 \mathrm{~g}$ smoked salmon

$100 \mathrm{~g}$ seal liver

$300 \mathrm{~g}$ seal muscle

$100 \mathrm{~g}$ seal blubber. 
The seal muscle and liver were minced with blubber, shaped into 'sealburgers' and fried in fish oil. The foods most commonly eaten were canned salmon, kippers and seal. Sinclair knew that, because his diet contained so much of the polyunsaturated fatty acids, he was likely to be short of vitamin $\mathrm{E}$, so from day 21 he took the precaution of adding $150 \mathrm{mg}$ of $\alpha$-tocopherol acetate. He relied on seal muscle and fish liver for vitamin $\mathrm{C}$, and his daily intake averaged $14 \mathrm{mg}$.

Before he started his 'Eskimo' diet, Sinclair knew that it would contain a large amount of cetoleic acid, an isomer of erucic acid, which is present in fish oil. This fatty acid had been reported to cause cardiac damage in rats, and there was also a suggestion that it was the cause of sudden cardiac arrest and death in Icelandic men. It was for this reason that Sinclair decided to make this experiment on himself alone, and in fact on three occasions he recorded sharp cardiac pain, with pronounced sinus arrhythmia.

Intake of the n- 6 fatty acids was low and that of the n-3 series high, so that the ratio n-6/n-3 was consistently $1 / 8$. On a western type diet the ratio is between about $4 / 1$ and $10 / 1$. Cholesterol intake was very high, rising to over $2000 \mathrm{mg}$ daily. In spite of this the plasma cholesterol remained in the range $3.1-6.8 \mathrm{mmol} / 1$ during the 100 days. Sinclair lost weight during the first 4 weeks; his weight fell from 96 to $84 \mathrm{~kg}$ because his energy intake fell to about half its customary value.

Large numbers of blood tests were made throughout the experiment, including platelet function, clotting factors, lipoproteins and the fatty acid profiles of different lipid constituents. Biopsies of skeletal muscle and adipose tissue were taken, insulin and glucose tolerance tests were made, and the ECG followed after exercise. The most striking finding seems to have been that there was extreme disaggregation of platelets, and bleeding time rose from 3-4 minutes to more than 50 minutes, which he concluded was due to his metabolic processes having 'substituted' 3 -series prostaglandins for the more usual 1-and 2 -series. He had spontaneous haemorrhages. Sinclair concluded that his self-experiment showed the great importance of the long-chain fatty acids of the $n-3$ series in decreasing the aggregation of platelets and therefore in the prevention of coronary artery thrombosis.

During the last ten years of his life Sinclair adhered rigidly to a diet low in saturated fatty acids and high in polyunsaturated fatty acids, primarily linoleic acid from his daily quota of corn oil. It also frequently included n-3 fatty acids from his favourite fish, mackerel. His lifestyle was thus determined by the results of his self-experimentation, and his body tissues continued to be frequently analysed. The results of this experiment are being prepared for publication.

\section{CONCLUSIONS}

This review of self-experimentation in nutrition research is a historical one, illustrating how scientists have used themselves to investigate changes in their physiology or biochemistry brought about by some alteration in their nutrition. The experiments were not without risk. Stark died of scurvy, Crandon and McCance became unconscious while making tests on themselves during their deficiencies, Herbert became temporarily paralysed, Sinclair's heart gave cause for concern on three occasions and Professor McCance and I injected pyrogens into each other's veins with unpleasant effects. Most of these problems could have been avoided, and fortunately, apart from Stark, no permanent harm was done. Accidents might have occurred had the experiments been made on someone other than the investigator, but it seems likely that self-experimenters were willing to go to lengths that they would not impose on anyone else.

Almost all the studies described were made before local research ethics committees (LREC) were established to approve experiments on human beings. I am grateful to 
Dr Shah, Research Officer in Medical Ethics of the British Medical Association, for the following information concerning the ethics of self-experimentation today.

"Research in Britain, apart from that on embryos, is not governed by legislation. Therefore, there is no legal obligation for researchers to obtain independent ethical approval for studies... The B.M.A. considers that all research, both within and without the NHS, should be subject to LREC approval... Self-experimentation has not been discussed by our Ethics Committee, but our preliminary work suggests that no study should require self-experimentation that cannot be carried out on healthy volunteers in a controlled way. The guidelines for healthy volunteers should then apply."

A report issued by the Royal College of Physicians (Anon 1986) states: "In Britain there is a long tradition of investigators doing research on themselves. We would not wish to discourage this, but anyone who desires to experiment on himself should seek the guidance of the Ethics Committee before doing so."

It would be interesting to know which of the self-experiments described here would have been approved by an Ethics Committee, had such Committees existed when they were made. All the self-experimenters (or one of the pair if there were two) were medically qualified, and they would have been aware of their ethical responsibilities towards themselves and their partners. However, in the stress of the dietary deficiency it may have been difficult to be objective, and it was the unexpected that produced the risk in the selfexperiments described here. The incidents that occurred show how important it is to have a colleague available to be called upon at all times who understands fully what is going on and what to do in case of emergency.

Self-experimentation has been deemed by some as unnecessarily 'heroic'. 'Heroic' it may have been but it has provided information that at the time would have been difficult to obtain in any other way.

I am grateful to Dr Mary Gale for all the help she has given me in putting together a brief story of Hugh Sinclair's self-experimentation on the Eskimo diet. I also thank Sir Douglas Black and Professor Maureen Young for their assistance over my search of the literature.

\section{REFERENCES}

Altman, L. K. (1987). Who Goes First? The Story of Self-experimentation in Medicine. New York: Random House.

Anon. (1986). Research on Healthy Volunteers. London: Royal College of Physicians.

Baker, H., Herbert, V., Frank, O., Pasher, 1., Hutner, S. H., Wasserman, L. R. \& Sobotka, H. (1959). A microbiologic method for detecting folic acid deficiency in man. Clinical Chemistry 5, 275-280.

Bernard, C. (1865). Introduction à l'Étude de la Médecine Expérimentale. Paris: Baillière et Fils.

Bicknell, F. \& Prescott, F. (1946). The Vitamins in Medicine, 2nd edn. London: Heinemann.

Black, D. A. K. \& Milne, M. D. (1952). Experimental potassium depletion in man. Clinical Science 11, $397-415$.

Black, D. A. K., McCance, R. A. \& Young, W. F. (1944). A study of dehydration by means of balance experiments. Journal of Physiology 102, 406-414.

Carpenter, K. J. (1986). The Hislory of Scurvy and Viramin C. Cambridge: Cambridge University Press.

Chittenden, R. H. (1904). Physiological Economy in Nutrition, with Special Reference to the Minimal Protein Requirement of the Healthy Man: an Experimental Study. New York: Stokes.

Crandon, J. H. \& Lund, C. C. (1940). Vitamin C deficiency in an otherwise normal adult. New England Journal of Medicine 222, 748-752.

Crandon, J. H., Lund, C. C. \& Dill, D. B. (1940). Experimental human scurvy. New England Journal of Medicine 223, $353-369$.

Drummond, J. C. \& Wilbraham, A. (1935). William Stark M.D. An eighteenth-century experiment in nutrition. Lancet ii, $459-462$.

Drummond, J. C. \& Wilbraham, A. (1939). The Englishman's Food: A History of Five Centuries of English Diet. London: Jonathan Cape.

Elvehjem, C. A., Madden, R. J., Strong, F. M. \& Woolley, D. W. (1937). Relation of nicotinic acid and nicotinic acid amide to canine black tongue. Journal of the American Chemical Society 59, 1767-1768. 
Elvehjem, C. A., Madden, R. J., Strong. F. M. \& Woolley, D. W. (1938). The isolation and identification of the anti-black tongue factor. Journal of Biological Chemistry, 123, 137149.

Fourman, P. (1954). Depletion of potassium induced in man with an exchange resin. Clinical Science 13, 93-110.

Garton, G. A. (1990). Metabolism of $n-6$ and $n-3$ fatty acids in man and animals. Biochemical Society Transactions 18, 755-756.

Goldberger, M. F. (1956). Dr. Joseph Goldberger. His wife's recollections. Journal of the American Dietetic Association 32, 724-727.

Haldane, J. B. S. (1940). On being one's own rabbit. In Possible Worlds, pp 105-119. London: Evergreen Books (Heinemann).

Herbert. V. (1962). Experimental nutritional folate deficiency in man. Transactions of the Association of American Physicians 75, 307-326.

Hervey, G. R. (1957). Drinking sea-water. Lancet 272, 533-534.

Hindhede, M. (1913). [Studies on the minimum protein requirement.] Skandinavisches Archiv für Physiologie 30, 97. 182.

Lind, J. (1753). A Treatise of the Scurvy. Edinburgh: Sands, Murray \& Cochran.

Lusk, G. (1928). The Elements of the Science of Nutrition, 4th edn. Philadelphia, PA. W. B. Saunders.

McCance, R. A. (1936a). Experimental sodium chloride deficiency in man. Proceedings of the Royal Society of London B 119, 245-268.

McCance, R. A. (1936b). Medical problems in mineral metabolism. 3. Experimental human salt deficiency. Lancet i, 823830 .

McCance, R. A. (1933). Autobiography. In McCance and Widdowson. A Scientific Partnership of 60 Years, pp. 19-30. [M. Ashwell, editor]. London: British Nutrition Foundation.

McCance, R. A. \& Widdowson, E. M. (1937). The fate of the elements removed from the blood stream during the treatment of polycythemia by acetyl-phenylhydrazine. Quarterly Journal of Medicine 6, 277286.

McCance, R. A. \& Widdowson, E. M. (1938). The absorption and excretion of iron following oral and intravenous administration. Journal of Physiology 94, 148-154.

McCance, R. A. \& Widdowson, E. M. (1939a). The fate of calcium and magnesium after intravenous administration to normal persons. Biochemical Journal 33, 523529.

McCance, R. A. \& Widdowson, E. M. (1939 b). The fate of strontium after intravenous administration to normal persons. Biochemical Journal 33, 1822-1825.

Martin, C. J. \& Robison, R. (1922). The minimum nitrogen expenditure of man and the biological value of various proteins for human nutrition. Biochemical Journal 16, 407-447.

Olliver, M. (1940). Antiscorbutic values of fruits and vegetables. Lancet 239, 190-192.

Panel on Dietary Reference Values of the Committee on Medical Aspects of Food Policy. (1991). Dictary reference values for food energy and nutrients for the United Kingdom. Report on Health and Social Subjects, No. 41. London: H.M.S.O.

Sivén, V. O. (1900). [Nitrogen balance in man during growth.] Skandinavisches Archiv für Physiologie 10, 91-148.

Sivén, V. O. (1901). [Metabolism in man during growth with special reference to protein shortage.] Skandinavisches Archiv für Physiologie 11, 308-332.

Stefansson, V. (1956a). The field experience. The Fat of the Land, pp. 52-53. New York: Macmillan.

Stefansson, V. (1956b). The laboratory check. The Fat of the Land, pp. 60-89. New York: Macmillan.

Sydenstricker, V. P. (1953). The impact of vitamin research upon medical practice. Proceedings of the Nutrition Society 12, 256-269.

Sydenstricker, V.P. (1958). The history of pellagra, its recognition as a disorder of nutrition and its conquest. American Journal of Clinical Nutrition 6, 409.414.

Widdowson, E. M. (1980). Adventures in nutrition over half a century. Proceedings of the Nutrition Society 39, 293-306.

Wolbach. S. B. (1953). Experimental scurvy. Its employment for the study of intercellular substances. Proceedings of the Nutrition Society 12, 247254.

Zalusky, R. \& Herbert. V. (1961). Megaloblastic ancmia in scurvy with response to 50 microgm. of folic acid daily. New England Journal of Medicine 265, 1033-1038. 